\title{
The Reception of Pistis Sophia and Gnosticism
}

\section{Uncovering the Link Between Esoteric Milieus and Contemporary Academia}

\author{
Paul Linjamaa \\ Centre for Theology and Religious Studies, Lund University, Lund, Sweden \\ paul.linjamaa@ctr.lu.se
}

\begin{abstract}
This article surveys the reception of the Gnostic text Pistis Sophia in esoteric milieus in nineteenth-and early twentieth-century Europe. The first part of the article contains an overview of the text and scholarship on it. Then follows a study of the reception of Pistis Sophia in a broader array of esoteric circles. It becomes clear that the text was hailed as an example of ancient and great spiritual wisdom, although seldom discussed in detail theologically. Next, this is compared to the academic reception at the same time where it was, as previous scholars have made clear, discarded due to what was understood as a discrepancy with "Gnostic" characteristics. This article shows that Pistis Sophia was not discarded in esoteric circles but rather read in light of already established esoteric trajectories, for example Blavatsky's, Krumm-Heller's, or Papus' particular spiritual evolutionary perspectives. Lastly, it is argued that the understanding of Gnosticisms that both these receptions reflect is still very much active today: academics and esoteric groups are guided by similar trajectories vis-à-vis Gnosticism, seeing it as a representative of a "universal religious essence" associated with progressive attitudes (for example regarding sex and gender), which allows/forces them to renegotiate the ancient sources themselves.
\end{abstract}

\section{Keywords}

reception of Gnosticism - Pistis Sophia - esotericism - Counter Culture - theosophy Ancient Wisdom Tradition - libertinism

This article contributes to a neglected topic in studies of western esotericism: the reception of ancient Gnostic sources in esoteric movements. Many 
introductory works on western esotericism discuss the significance of Gnosticism, and rightfully so. ${ }^{1}$ Central personalities in the long history of western esotericism — ranging from Paracelsus (1493-1541), Jacob Böhme (1575-1624), and Emanuel Swedenborg (1688-1772) to Helena Petrovna Blavatsky (18311891), Gérard Encausse (1865-1916), and Aleister Crowley (1875-1947)-have hailed the superiority of the ancient knowledge belonging to so-called Gnostics. However, as has become clearer during the last few decades, Gnosticism is anything but a straightforward category. ${ }^{2}$ After the discovery of many new sources in the twentieth century, it became clear that representations of Gnosticism by the church fathers in antiquity seldom fitted with the sources.

So, what exactly did one mean when referring to ancient Gnosticism in the nineteenth and early twentieth centuries? This question has been studied from the perspective of theological debates of the period. Karen King, for example, has argued convincingly that "Gnosticism" seldom referred to a specific religious phenomenon, nor was it used to define a set of individuals or groups. It seems rather to have been used as a wastebasket category for anything heretical. ${ }^{3}$ This way of using the term has apologetic motives, going back to the polemical context of antiquity. But what about in esoteric circles, where "Gnosis" was more often than not upheld as a positive? This article will begin answering this question by scrutinizing how one of the few Gnostic texts available at the time, Pistis Sophia, was viewed in nineteenth- and early twentiethcentury European esoteric movements. ${ }^{4}$ This period witnessed the birth of many important esoteric movements, such as the Theosophical Society, Martinism, and the Ordo Templi Orientis (ото). The period would also generate a new surge in the academic study of Gnosticism, partly due to the discovery in 1789 of the Gnostic text which is the focus of this study, a text that soon came to be viewed as the first and ultimate source for ancient Gnosticism.

1 Hanegraaff, Western Esotericism, 18-25; Faivre, Access to Western Esotericism, 51-55.

2 The two most significant works where this is discussed are Williams, Rethinking "Gnosticism," and King, What is Gnosticism?.

3 King, What is Gnosticism?, 24-54.

4 What is missing in the present study is the reception of Pistis Sophia in Russian esoteric milieus. This is most likely of great interest and there have recently been attempts to study the reception of Gnosticism in the east. See for example the study on the ideas of George Ivanovich Gurdjieff by Churton, Deconstructing Gurdjieff. This particular work, however, has received critique for being methodologically unsound (Azize, 'Assessing Borrowing,' 1-30). It, nevertheless, points out a path forward; one that should yield interesting results. 
This article will not only scrutinize the reception of Gnosticism among European esoteric movements, but also cast new light on how academic and esoteric milieus, often studied independently, related to each other. It will be argued that there are important parallels between the two.

A comprehensive study of the reception of Pistis Sophia within academia and by groups and individuals associated with esotericism would result in a very thick volume, much larger than the study offered here. Thus, what follows is a selection of points for consideration, but a selection that aims to point out propensities hitherto overlooked vis-à-vis the relation between academics on the one hand and esoteric milieus on the other-insights that will hopefully generate further study. The first half of the article comprises an overview of the text and the history of scholarship on Gnosticism and Pistis Sophia. This part does not contain many previously unnoticed insights, but is intended to serve as an introduction to the subject of Pistis Sophia, ancient Gnosticism, and their history of research. The second half is devoted to the reception of Pistis Sophia in esoteric circles, which will allow us, in light of the first part, to observe both similarities and differences between academic and esoteric receptions.

\section{Accessing Gnosticism in Nineteenth- and Early-Twentieth-Century Europe}

Most of what is known today, as well as throughout modern history, regarding the many ancient religious and philosophical groups and individuals associated with Gnosticism has come down to us through the writings of the church fathers. These writings were composed in order to refute the theology of particular groups and individuals who were considered a threat to "orthodox" Christianity. Naturally, these writings were polemically inspired and thus it is often difficult to separate descriptions of historical people and their actual beliefs and practices from elaborate exaggerations and outright fabrications, made up in the name of what the church fathers considered a good cause (protecting their version of orthodoxy). Today, we have access to many texts written by the Gnostic "heretics" themselves which can help us read the secondary source material critically. One such example is the famous Nag Hammadi collection, $5^{2}$ texts bound in twelve papyri codices. These are Coptic translations from around the middle of the fourth century, from what seem to have been earlier Greek texts (at least in most cases). ${ }^{5}$ In the collection we find Valentinian writ-

5 Lundhaug and Jenott, The Monastic Origins. 
ings, ${ }^{6}$ Sethian material, ${ }^{7}$ and a plethora of miscellaneous apocrypha of variable Christian origin. These texts, and many others extant today, were not available in nineteenth-century Europe.

However, people in the nineteenth and early twentieth centuries did not only have the church fathers' depictions of so called "Gnostics" to rely on; there were some original texts associated with Gnosticism available even then. One of the famous source collections for ancient Gnosis is the Corpus Hermeticum, an assortment of different Hermetic writings, some of which are as early as third or even second century. ${ }^{8}$ Apart from this Hermetic collection, widely studied since its re-discovery in the Latin west, there were not many original texts by other ancient "Gnostics" accessible to the European readership. This was the case until the end of the eighteenth century, when two ancient codices were discovered just a few years apart. One of these was the Bruce Codex, which has its name from James Bruce, the Scottish traveler who purchased the codex in Egypt around 1769. This manuscript contains two texts: one is known today as The Books of Jeu (in two "books" or parts), and the other, for lack of a better title, has simply been called the Untitled Text in the Bruce Codex. These texts present and describe the complex architecture in the innermost heavenly realms. ${ }^{9}$ The Bruce Codex does not seem to have received much attention or any wide readership in the nineteenth century, even after its translation into modern languages. ${ }^{10}$ According to Erin Evans, who has carried out one of the few studies into the codex, the Books of Jeu contain instructions for teachers, priests, and ritual instructors which are not meant for everyday use. They were used as handbooks for advanced study of the complicated mystical landscape of the highest realms of "treasuries". Recently, the neglected study of the Books of Jeu has received additional attention, chiefly by Eric Crégheur..11

$6 \quad$ For example The Gospel of Truth, The Tripartite Tractate, The Gospel of Philip, The Interpretation of Knowledge, and A Valentinian Exposition. For a definition of the term and why these texts could be called Valentinian, see Linjamaa, The Ethics of The Tripartite Tractate, 7-12.

7 For example Apocryphon of John, The Three Steles of Seth, The Hypostasis of the Archons, Trimorphic Protennoia, Marsanes, Second Treatise of the Great Seth, Allogenes. For more on the nature of Sethianism, see Rasimus, Paradise Reconsidered.

8 The latest and most thorough work on ancient hermeticism is Bull, The Tradition of Hermes Trismegistus.

9 For more on the Books of Jeu and their relation to parts of Pistis Sophia, see Evans, The Books of Jeu.

10 Evans, The Books of Jeu, 1, 5-8.

11 Crégheur, Les "deux Livres de Iéou". See also a study that investigates the relationship between the Bruce Codex and Book IV of Pistis Sophia, by Johnston, 'Proximité littéraire,' $85^{-107}$. 
Just a few years after the Bruce Codex was discovered, another ancient codex containing Gnostic material appeared - a more reader-friendly text with a more accessible narrative. This text received a very different reception and a much wider readership than the texts in the Bruce Codex.

A Brief Exposé of the Configuration and Contents of Pistis Sophia ${ }^{12}$

In 1773 an English physician and bibliophile, Anthony Askew, came into possession of a manuscript, known today as the Askew Codex. ${ }^{13}$ This codex contained a Coptic Gnostic text that became known as Pistis Sophia. The text, as we shall see, was hailed by many as the ultimate source on ancient Gnosticism. The codex was bought by the British Library shortly after Askew died in 1774, and has remained there ever since (MS. Add. 5114).

Given its age, the Askew Codex contains a very well-preserved parchment manuscript ${ }^{14}$ comprising 174 leaves (originally 178 ), a total of 345 pages of text. ${ }^{15}$ Pistis Sophia consists of four parts, or "books," but there is no title on the opening page, which is not uncommon for ancient manuscripts. On the top of page 115, above the two columns of text, we read пмєе сNаץ $\overline{\mathrm{N}}$ томос $\overline{\mathrm{N}}$ тпістіс copld ('The Second Book of the Pistis Sophia'). This heading may very well have been a later addition, but it is this title that became used in modern times. ${ }^{16}$ There is another possible title appearing within the text. Both book II (twice, on page 233a and 234b) and book III (page 318a) end with the words orme-

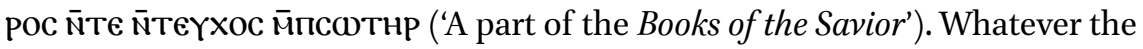

12 I wish to extend my thanks to the British Library for allowing me to study the manuscript in person, and for photocopying the entire manuscript for me. Unfortunately, Pistis Sophia remains to be published as a facsimile, which is a shame considering its well-preserved and legible state.

13 According to the Coptic scholar Karl Gottfried Woide, Askew purchased the manuscript from a bookseller. Woide was the librarian at the British Library at the time Pistis Sophia was purchased, and he makes this statement in a letter to Johann David Michaelis, a famous biblical scholar at the time. Bulhe, Literarischer Briefwechsel, InI:69. Another story of how Askew came into possession of the manuscript comes from Köstlin, who writes that Askew bought it on his travels in Italy and Greece. Köstlin, 'Das gnostische System,' 1.

14 The text is in a clear and legible Sahidic, written in two columns per page. Paleographical analysis determines that there were most likely two scribes working on the text. The leaves measure $21 \times 16.5 \mathrm{cms}$ and the codex was at some point re-covered, now enclosed in a modern casing. See Schmidt and MacDermot, Pistis.

15 The first three pages do not contain script, apart from notes from the previous owners. For example, on the top right corner of the first page of the text is written 'A Askew M.D.'

16 See Schmidt and MacDermot, Pistis Sophia, xiii. 
ancient name of the text at hand was, the work bound in the Askew Codex was most likely a conglomerate of texts not originally composed with the intention of being bound in the manner we have them now. ${ }^{17}$ And as the few scholars working on the Books of Jeu have noticed, there are striking parallels between parts of Pistis Sophia (book IV) and the Books of Jeu, particularly in the cosmology. These details could reflect a shared original context. ${ }^{18}$

The main characters of the Pistis Sophia are Jesus (also called the Savior, and the First Mystery), Pistis Sophia (or Faith Wisdom), and Mary Magdalene. Some of the disciples and a plethora of heavenly beings also appear frequently, like the Archons, Aeons, Fate (Heimarmenē), and the Demiurge. Book I opens with a description of the teachings of Jesus and describes how Jesus ascends after his death in a garment of light and casts down rebellious heavenly beings who oppose him. This is followed by the answers that the resurrected Jesus gives to a number of questions posed by Mary Magdalene and the disciple Philip. Jesus explains how he rescued Pistis Sophia who was stuck in the chaos of the world, and how she offered him songs of praise in return. These events are, in a somewhat similar manner, repeated in book II. There, Jesus is called the First Mystery, and much attention is given to the importance of uncovering different "mysteries". The book ends with Jesus answering questions posed to him by different disciples. Book III begins by recounting the importance of renouncing the world in favor of the Kingdom of Light and Jesus describes the nature of the relation between the human soul, intellect, and body, and the human bondage to Fate. Again, Mary Magdalene poses a number of questions to Jesus, this time regarding the nature of the heavenly planes above the earth and the opposition humans encounter from different heavenly powers. The fourth and last book recounts the workings of the planetary realms, the zodiac, and how different archons tempt humans to sin. Jesus then describes how people avoid temptation through the offering of prayers and by following different rituals (like baptism).

There are some studies on the reception of Pistis Sophia in the religious and academic milieu of the nineteenth to twentieth centuries in Europe. Franz Winter recently published an article on Samael Aun Weor's (1917-1977) readings of Pistis Sophia, which also notices the importance of Pistis Sophia in the works of Arnold Krumm-Heller (1876-1949). ${ }^{19}$ The present study focuses on the time before Samael Aun Weor. Another recent study on the reception

17 There are several indications of this. For example, the repetition in the storyline and the fact that Jesus is called by different epithets through the different books.

18 For more on this, see Johnston, 'Proximité littéraire', 85-107.

19 Winter, 'Studying the "Gnostic Bible", 83-112. 
of Pistis Sophia - a draft of which I have read and from which I was greatly inspired - is the introductory chapter of an as yet unpublished dissertation on the ancient intertextuality of the Pistis Sophia by Petter Spjut. ${ }^{20}$ Spjut argues that preconceived notions of what Gnosticism was thought to be-influenced mainly by the church fathers' polemical descriptions of the phenomenon-led scholars in the nineteenth and early twentieth centuries to ignore the text as a representation of "pure" Gnosticism. Spjut's conclusion reiterates and expands upon Karen King's observation in her 2003 work What is Gnosticism?. ${ }^{21}$ According to King, Pistis Sophia was dismissed by theologians as a distorted form of a previously pure phenomenon. Spjut, however, deepens King's initial observation and finds it applicable to theologians and religious scholars such as Hans Jonas, Adolf von Harnack, K.R. von Köstlin, Charles Josias Bunsen, and Hans Leisegang. He also mentions one representative of the esoteric milieu: G.R.S. Mead.

The following study is intended to broaden these significant scholarly contributions by including a wider array of esoteric figures and looking at how they received the Pistis Sophia. By examining the reception of Pistis Sophia, the article aims to shed some light on the relation between academia and esoteric milieus of the nineteenth to twentieth centuries. Before this comparison commences, however, the academic reception of Pistis Sophia should be revisited briefly.

The Reception of Pistis Sophia in Nineteenth-Century Academia: The Beginnings of Gnostic Studies

The nineteenth century would generate a wealth of scholarship as well as general interest in Gnosticism. Much of the earliest academic productions concerning Pistis Sophia dealt with the text's origin, authorship, and dating. By far the most widespread hypothesis was that Pistis Sophia was a text written by Valentinus, the famous second-century Christian preacher from Egypt, "originator" of the famous "heresy" Valentinianism. This was already suggested by Carl Gottfried Woide (it remains, however, unclear on what grounds), the librarian at the British Library in London who showed interest in the text from the

20 Petter Spjut, in the dissertation chapter entitled 'Pistis Sophia and the Chimera of Gnostic Origins.' My study is different from Spjut's, in that it focuses on esoteric milieus, which Spjut does not discuss, save for Mead.

$21 \quad$ King, What is Gnosticism?, 81. 
very beginning of its discovery. ${ }^{22}$ This became a popular hypothesis, although it would not remain unchallenged.

At the time Pistis Sophia was first discovered, Coptic was a neglected ancient language in comparison to Greek, Hebrew, and Latin. ${ }^{23}$ Thus, before the first translations of the text appeared, Pistis Sophia remained fairly neglected in fields like patristics, classics, and biblical studies. With the exception of the few mentions of Pistis Sophia in writings by the librarian Woide, ${ }^{24}$ the earliest mentions in published scholarly works are found in the writings of Friedrich Münter, bishop in the Danish Church and professor of theology at the University of Copenhagen. Münter became interested in Pistis Sophia on account of quotes we find in the text from the Odes of Solomon. In the nineteenth century, the odes were only known in Latin, by way of Lactantius. ${ }^{25}$ In 1812, Münter published an article on the odes in Pistis Sophia. In it, he mentions the text as a whole. ${ }^{26}$ Münter's article represents one of the earliest and chief areas of interest in the text among academics: what it could tell us about other things than the text itself (in this case, the Odes of Solomon). ${ }^{27}$

The first translation of Pistis Sophia was published in 1851, a Latin rendition by a professor of Coptology in Berlin, Moritz Gotthilf Schwartze. ${ }^{28}$ Schwartze had been sent to London by the Prussian Royal Academy with the task of providing a translation of the text, but he died in 1848 just before finishing his work. The task of finalizing the publication was taken on by Schwartze's fellow orientalist, J.H. Petermann, who edited the final draft for publication in 1851.

It would take almost 100 years from the discovery of the text in 1796 until a translation appeared in a modern language. A French translation was first produced in 1885, by the French Coptologist Émile Amélineau. ${ }^{29}$ According to Amélineau, there had been an earlier French translation of the text, by Édouard Dulaurier, but this translation does not seem ever to have been published and thus never reached the general public, nor a wider scholarly circle. ${ }^{30}$ Amélineau's translation from 1885 became the first translation which was broadly

22 Woide, 'Fragmenta Novi Testamenti,' 137.

23 Krause, 'Coptological Studies,' 613a-616b.

24 See above note and Woide's comment in Cramer, Beyträge zur Beförderung, 82.

25 Harnack, History of Dogma I, 226.

26 Münter, Odae Gnosticae Salomoni, 1-32.

27 This topic will be discussed further below.

28 Schwartze, Pistis Sophia.

29 Amélineau, Pistis-Sophia.

30 Amélineau, Pistis-Sophia, 5; Dulaurier himself writes that he had copied the manuscript while staying in London and made a translation, and that he meant to publish it, but it seems that he never did. See Dulaurier, 'Notice sur le Manuscript,' $534-548$. 
distributed, read, and quoted. His work was preceded by a detailed 5o-page introduction, where he, just like Schwartze had done, argued that the text was written by Valentinus. Amélineau's widely read translation was most likely one of the main reasons why this became such a common view in the popular reception of the text. The Valentinian background of Pistis Sophia is all but abandoned today due to the text's many discrepancies with what we now know about Valentinianism. ${ }^{31}$ Amélineau dated the manuscript to somewhere around the tenth century, but this position, in contrast to the question regarding authorship, never received any support, since most scholars would date the text to around the third or fourth century. ${ }^{32}$

The first translation into English was presented by the Theosophist and scholar George Robert Stowe Mead (1863-1933) at the end of the nineteenth century. Mead was widely read and a master of several languages, but he did not read Coptic. Thus, the first translation into English of Pistis Sophia was a translation of a translation: Schwartze's Latin version. ${ }^{33}$ Mead later revised his translation and checked and compared it to Amélineau's French translation. Mead's initial translation was published in piecemeal form in the theosophical journal Lucifer (later the Theosophical Review) in 189o-1891. A few years later, in 1896 , the whole text was published as a book. ${ }^{34}$ Mead, who early on had been a supporter of the Valentinian origin hypothesis, would later reject this view in light of new research. One of the chief hypotheses that countered the Valentinian hypothesis was first forwarded by the German theologian Karl Reinhold von Köstlin in 1854, and was supported by Adolf von Harnack..$^{35}$ Epiphanius had written that some Gnostic groups, such as the Ophites, held Mary Magdalene and Philip in high regard, and since Pistis Sophia (as we have seen) mentions these two by name (Mary several times), it was suggested that Pistis Sophia reflected an Ophite background. Mead, however, had a hard time accepting this thesis since the text did not give the serpent any attention, which Mead viewed as the chief characteristic of those groups the church fathers labeled as "Ophites" (ophis meaning snake). ${ }^{36}$

31 See, for example, Evans, The Books of Jeu, 3; Crégheur, 'En amont de la découverte de Nag Hammadi,' 217-233.

32 Schmidt and MacDermot, Pistis Sophia, i-xii.

33 Actually, a translation of a translation of a translation, if we take into consideration that Pistis Sophia was most likely first written in Greek.

34 Mead, Pistis Sophia.

35 Köstlin, 'Das Gnostische System Des Buches Pistis Sophia.' For a comparison of these three scholars view of the text—Mead, Harnack, and Köstlin—see Spjut, 'Pistis Sophia and the Chimera of Gnostic Origins.'

36 Mead, Pistis Sophia: A Gnostic Gospel, xxxi-xxxiii. 
The translation that enjoyed greatest recognition and which has had the most longevity is the German translation by one of Harnack's pupils, the Coptologist Carl Schmidt. Schmidt began publishing works on Pistis Sophia in the beginning of the twentieth century. His translations and transcriptions are painstakingly thorough and are still in use today. ${ }^{37}$ The only other English translation apart from Mead's was that of the Bible scholar George Horner, which appeared in 1924. Horner's translation was based on the Coptic original. However, he kept the Coptic word order as it stood in the manuscript and limited interpretations to a minimum. This resulted in an extremely odd read, bordering on the incomprehensible, which was probably the reason Horner's translation never attained a wider readership. It was not until 1978 that an English version came out that was readable and based on the actual Coptic text of Pistis Sophia. This was by Violet MacDermot, based on Schmidt's transcriptions, and is a standard work most scholars use today when referencing the text in English. ${ }^{38}$

The renditions of the text into modern languages which started to appear in the second half of the nineteenth century would generate a much larger interest in the text. Schmidt wrote that, due to the great popularity of 'orientalische Theosophie und Mystik, ${ }^{39}$ his first edition of the text sold out, prompting his publisher to make him produce a second edition. This he dedicated to all the new and old lovers of Gnostic literature whom he thought would greatly enjoy Pistis Sophia. ${ }^{40}$ The hypothesis that Pistis Sophia was a text by Valentinus was also, as we have seen, challenged after the text became available to scholars other than Coptologists.

One of the earliest works on the nature of Gnosticism, and one that also mentions Pistis Sophia, was by the writer and gem collector Charles William King, fellow at Cambridge. In his book, The Gnostics and their Remains from 1864, he traces the origins of Gnosticism to India. In the second edition of the book, from 1887, he spends several pages discussing Pistis Sophia.${ }^{41}$ He treats

37 Carl Schmidt, Koptisch-gnostische Schriften. Republished several times, in 1954, 1959 and 1962.

38 Schmidt and MacDermot, Pistis Sophia.

39 Schmidt, Pistis Sophia: Ein Gnostisches Originalwerk, 1.

40 He ends his introduction to the new edition by writing thus: 'So möge denn diese Übersetzungsausgabe in ihrem neuen Gewände neben den alten Freunden neue Liebhaber für die uns heute so seltsam anmutende gnostische Literatur gewinnen!' (Schmidt, Pistis Sophia: Ein Gnostisches Originalwerk, 2).

41 Pistis Sophia is not mentioned in the earliest editions of this work, but the edition from 1887 discusses the text in light of Schwartze's translation. See King, The Gnostics, 14-18. 
the text as a rare example of a long-lost Gnostic tradition, and notes in particular the prominent place of Mary Magdalene. King's short survey of the text demonstrates that he studied the text thoroughly, giving a fine overview of the complex content. Here, we have an example of a scholar who viewed the discovery of Pistis Sophia as highly interesting and immensely valuable, not an example of something diluted or worthless. ${ }^{42}$ As we will see shortly, this book had a large reception in some esoteric circles.

What becomes clear when studying the earliest scholarship on Pistis Sophia is that it was seen as a secondary source for the history of orthodox Christianity. ${ }^{43}$ Interestingly, some scholars who were interested in the actual phenomenon of Gnosticism neglected Pistis Sophia to a large extent. As has been suggested by other scholars, this was most likely because the text did not actually fit with what Gnosticism was thought to be at the time. ${ }^{44}$

The history of the term "Gnosticism" has been thoroughly studied by many scholars. ${ }^{45}$ The term first appears in the writings of Protestant apologetic author Henry More, who, in 1669, argued that Catholicism was like the "ancient Gnosticism" that seduced true Christians into idolatry and paganism. ${ }^{46}$ Theologians and historians of religion alike had long been searching for the "essence" of Gnosticism. The German philologist Richard Reitzenstein viewed Gnosticism as inherently dualistic, born out of Jews' and Christians' exposure to the east and blending of the Judeo-Christian myth with Iranian thoughts of the eternal struggle between Ahura Mazda and Ahriman. Reitzenstein gave much attention to Gnosticism in what is probably his most famous work, Die hel-

King notes that the text is attributed to Valentinus, but also writes that he 'knows not on what authority.'

42 In the preface to the second edition he writes that, as 'the only Gnostic Gospel preserved,' Pistis Sophia 'throws a light upon the terminology and machinery of the religion that, before its discovery and publication was perfectly unattainable,' and sees it, and the newly discovered Refutation of all Heresies of Hippolytus, as 'invaluable resources, which will be found doing good service in almost every section of the present work' (King, The Gnostics, $\mathrm{xv})$.

43 Karen King has previously studied the representation of the phenomenon of Gnosticism in scholarship and come to much the same conclusion (King, What is Gnosticism?).

44 King, What is Gnosticism?, 81; Spjut, 'Pistis Sophia and the Chimera of Gnostic Origins.'

45 Smith, 'The History of the Term Gnostikos,' 796-807; King, What is Gnosticism?. A recent trend among some scholars, not adopted here, is to narrow down the use of the terms 'Gnostic' and 'Gnosticism' to refer to the Sethian material, beginning with those Irenaeus first called 'multitude of Gnostics' at the end of book I of Against Heresies (Chapters 29-31). See Layton, The Gnostic Scriptures; Brakke, The Gnostics; and Rasimus, Paradise Reconsidered.

46 See an overview in King, 'What is Gnosticism?' 
lenistischen Mysterienreligionen (1927), still in print today. However, he did not mention Pistis Sophia in this work at all, even though it had been available to scholars for a long time. ${ }^{47}$ Looking at the content of the text, this should not surprise us. It is unclear where Pistis Sophia, which does not show any obvious resemblance to Zoroastrianism, would fit in Reitzenstein's trajectory of the development and origin of Gnosticism. ${ }^{48}$

While some scholars in the history of religion were engaged in finding the essence of Gnosticism, Christian theologians were engaged in finding the essence of Christianity. Among theologians Gnosticism became very useful as a counter-example against which Christianity could be defined. This is the way Adolf von Harnack, in his work Dogmengeschichte (1885), characterized Gnosticism: as 'the acute Hellenization of Christianity.'49 As the mentor of Carl Schmidt (who edited and translated Coptic texts), Harnack was well acquainted with Pistis Sophia and wrote a book in 1891 on the text. ${ }^{50}$ Here, he identifies the text as a variant of Gnosticism that fits well with his view of the development of Christianity overall: that the "original" form of Christianity, its "pure" form (read "that which resembles Protestantism"), had digressed into an overly ritualized form of Catholicism, on the one hand, and a syncretistic Gnosticism on the other. This idea, that there had been an original, pure form of Christianity in the first century which the Catholic Church had lost touch with, was firmly established in the Protestant tradition..$^{51}$ Rudolf Bultmann, however, another of the great nineteenth century theologians, did not view Gnosticism as having originated from Christianity. Rather, it was an earlier and less perfect religion which had failed to develop into the fulfilment which one could find in the Christian tradition. ${ }^{52}$ Bultmann was the mentor of one of the first real leading lights of what would become the field of Gnostic studies: the Jewish philosopher and historian Hans Jonas. Jonas was interested in Gnosticism as such, not only for what it could tell him about the development of Christianity. Still, he sought the essence of Gnosticism and was strangely uninterested in Pistis Sophia. He barely gave it any attention in his monumentally influential work Gnosis und spätantiker Geist (1935), viewing the text as a diluted form of a purer version of Gnosticism, which for him was an expression of late antique

47 Reitzenstein, Die hellenistischen Mysterienreligionen.

48 For other examples of scholars ignoring Pistis Sophia, see Spjut, 'Pistis Sophia and the Chimera of Gnostic Origins.'

49 Harnack, History of Dogma, 231.

$5^{\circ} \quad$ von Harnack, Über das gnostische Buch Pistis-Sophia.

51 For more on this topic, see Smith, Drudgery Divine, 1-36.

$5^{2}$ Bultmann, 'Points of Contact and Conflict,' $133^{-15}$ o. 
existential crisis. Influenced by his other mentors, Edmund Husserl and Martin Heidegger, Jonas traced the "spirit" of Gnosticism to a particular late ancient Zeitgeist, the feeling of littleness in a hostile world. ${ }^{53}$

In short, there was little to no consensus regarding the nature of Pistis Sophia among theologians or scholars in the history of religions. The reception of the text was shaped by preconceptions of what Gnosticism was supposed to entail. This has been observed by Karen King, who states that 'The materials of the Bruce and Askew codices were known, but they seemed to scholars to represent a late and degenerated form of Gnosticism, and thus to reveal little of real interest. ${ }^{54}$ As has been mentioned already, Petter Spjut has broadened this discussion. He showed that when Pistis Sophia was first discovered, the initial response among theologians was one of excitement, an excitement that soon turned into disappointment. ${ }^{55}$ King noted that what church fathers had described, and what some scholars expected to find in a first-hand source, did not fit neatly with Pistis Sophia. The form of Gnosticism we find in Pistis Sophia gives a lot of attention to Jesus, Mary Magdalene, and the other disciples, and does not focus much on the Demiurge, hatred of the world and the body, or strange rites. Nevertheless, as we have seen, there were many scholars engaged in translating, transcribing, and identifying the text who did not express disappointment but genuine interest, seeking to identify its content and background, and making it available to scholars and public readers who were very interested in the text. ${ }^{56}$ This enthusiasm did not seem to diminish. More importantly, there was another reception of the text altogether: the reception outside the confines of specialized academia.

One of the chief aims of the present article is to cast light on the intersection between academia and religion, between scholarly and spiritual pursuits, and between writings of scholarship and history on the one hand and confessional texts on the other. These two worlds are often kept apart and studied separately, with little attention given to the intersections between them. Looking closer at the reception of Pistis Sophia in both contexts will, I hope, elucidate the fact that the esoteric groups that blossomed around Europe during this time and the theologians and scholars in the universities had much in common, and

\footnotetext{
53 King, What is Gnosticism?, 10-15.

54 King, What is Gnosticism?, 81.

55 In the draft of Spjut's dissertation chapter, Spjut chiefly discusses Köstlin and Bunsen, who indeed clearly expressed this disappointment as they describe the text as a degenerate example of Gnosticism. Köstlin, 'Das Gnostische System Des Buches Pistis Sophia'; Bunsen, Hippolytus and His Age. Spjut mentions Harnack as the exception to this rule.

Like Woide, Schwartze, Amellieu, Mead, Schmidt, and many others.
} 
indeed drew upon each other to further their own causes. Finally, I will argue that some features of esoteric readings of Gnosticism still resonate among academic perspectives today. Before elaborating on this point further, we must first turn to the reception of Pistis Sophia in the esoteric milieus of Europe.

\section{The Reception of Pistis Sophia in Esoteric Milieus}

\section{1}

\section{Approaching the Common Ground in Academia and Esotericism: Pistis Sophia in Theosophy and The Quest}

One of the few academic works that discusses Pistis Sophia, which also seems to have had a large reception in esoteric circles, was Charles William King's book The Gnostics and their Remains from $1887 .{ }^{57}$ In a review of King's book published in the theosophical journal Lucifer, we are offered a rare glimpse into the way Pistis Sophia was viewed by Theosophists. The review is signed 'Adversary,' and it is possible that this refers to the general editor herself, Blavatsky. ${ }^{58}$ Even though Blavatsky recommends the book at other occasions, ${ }^{59}$ in this review (if it is by Blavatsky) she is critical and writes that had he [King] a greater intuitional power, and a knowledge of esoteric religion, his great industry and erudition would make his writing valuable even to students of Occultism.'60 The reviewer also states that there were two more ancient copies of Pistis Sophia, and criticized King for neglecting to mention them in his book. One of the versions of Pistis Sophia that King was supposedly unaware of - as well as, it should be added, all other scholars at the time and since-was an 'ampler copy than that in the British Museum.' This copy was supposedly in the possession of a Russian dissident named Raskolnik, a Cossack 'who lived and married in Abyssinia.' The second mysterious ancient copy of Pistis Sophia was, the reviewer writes, owned by an Englishman, an 'Occultist' residing in America,

57 As Hugh Urban notices, King's book was one of the chief sources for Blavatsky in Isis Unveiled when Gnosticism was discussed. Urban, 'The Knowing of Knowing,' 101.

58 'Review: The Gnostics and their Remains', 332-334. The most qualified Theosophist to write a review on a book on Gnosticism would undoubtedly be Mead. But it was not he who wrote it, which will soon become clear. I would venture to guess that this writer was Blavatsky, the general editor and chief writer of the journal. In her book Isis Unveiled, King's book seems to be the chief reference to her use of Gnosticism, which shows that she had read King's book thoroughly. In any case, it was not Mead. In none of his other writings on Pistis Sophia does he mention two other manuscripts, and he also gives a different review of his own that does not match the one published in Lucifer 4.

59 Urban, 'The Knowing of Knowing,' 101.

6o 'Review: The Gnostics and their Remains', 332. 
who got it from Syria. In a note, the reviewer writes that it is incorrect to assume that no one knew anything about Pistis Sophia before 1853; the Theosophists have always known this text best. The statements made by the reviewer concerning two other ancient copies of Pistis Sophia are impossible to verify today, and most likely reflect Theosophical propaganda intended to show who the real experts on Gnosticism were: Theosophists. Nevertheless, the review is an illuminating example of the overall positive reception of Pistis Sophia and Gnosticism in Theosophy.

The Theosophist who without doubt knew the text best in the Theosophical Society was Mead. ${ }^{61}$ Contrary to Lucifer's reviewer, he was impressed by King's work:

The simplest and fairest account of the text, from an exoteric standpoint, is to be found in the interesting and learned work of the late C.W. King, in which he speaks of Pistis-Sophia with the greatest enthusiasm, as the most precious and perfect relic of the followers of the Gnosis. Throughout his work he continually refers to it as the highest authority of Gnosticism still extant. ${ }^{62}$

Mead's interests in Pistis Sophia ran deep. As stated above, he produced the first English translation of the text and spent countless pages in theosophical journals exploring it as well as the writings of the church fathers. One of the differences between the academic and the esoteric reception of the text which is, perhaps, an obvious difference but one that should be stated regardless, was that while initial academic reception mainly consisted of trying to date the text and identify its author(s), the esoteric reception was immediately interested in the content, seeking to draw ancient wisdom from it. As Petter Spjut has pointed out, while Mead did not consider the text the most "original" or earliest form of Gnosticism (it was after all a later translation which seemed to have undergone editorial work already in antiquity), he still valued the text highly. ${ }^{63}$ He found it interesting enough to spend a large part of his scholarly endeavors reading, studying, and translating the text. Mead's enthusiasm spread to many other Theosophists. Blavatsky, even though she maintained that Theosophy was intimately linked with ancient Gnosticism and often made a point

$61 \quad$ Dylan Burns has recently published an interesting essay exploring Mead's studies of Pistis Sophia and the importance of the image of early Christians as opposed by Gnostics. Burns, 'Weren't early Christians up against a gnostic religion?,' 61-69.

62 Mead, 'Pistis Sophia', 107.

63 Spjut, 'Pistis Sophia and the Chimera of Gnostic Origins.' 
about this, ${ }^{64}$ rarely refers to Pistis Sophia directly, even though it was without doubt the most extensive representation of ancient Gnosticism available at the time. Annie Besant discusses the text in more detail in her work Esoteric Christianity: Or, The Lesser Mysteries. She placed quotes and theological stances from the text into a larger Christian context, and used the text as a reference regarding the nature of sin and the number of times a person may deny truth before being denied re-entry to the mysteries. ${ }^{65}$ Blavatsky, Besant, and Mead treated Pistis Sophia as an example of a deeper and hidden form of ancient Christianity which had been forgotten, a Christian version of the all-encompassing universal religious truth, in which all religions ultimately share. Blavatsky, Besant, and Mead, at least for large parts of Mead's life, called this all-encompassing quest for the truth Theosophy. As such, Pistis Sophia was a religious text among many others that deserved attention, but was in no way exclusive in its presentation of wisdom.

After Blavatsky's death, Mead would leave the Theosophical Society in the aftermath of the Leadbeater scandal. ${ }^{66}$ However, his interest in Gnosticism in no way diminished; on the contrary. In 1909 Mead founded the Quest Society together with a number of other Theosophists who had left the Theosophical Society due to the conflict. They continued the quest for ancient wisdom in all kinds of ancient and foreign religions, and published a journal. This journal was named The Quest: A Quarterly Review, and was academic in nature. There, Pistis Sophia is frequently mentioned and used as a source for, and as an example of, ancient Gnosis. Several famous academics published articles on topics such as Buddhism, Chinese religion and philosophy, and ancient Greek and Roman religion in The Quest. Bultmann was a contributor and published some of his early works on Mandeism (1925-1926), and Gershom Scholem wrote on Jewish mysticism (1925-1926).

The interest in Pistis Sophia amongst the Theosophical Society did not disappear with the exit of Mead. In 1935 the novelist and Theosophist Mrs Muirson Blake, writing under the pseudonym Jean Delaire, wrote an article in the Occult Review entitled 'The "Fifth Gospel".'67 She writes that, in Christianity, there was

64 See Blavatsky, Isis Unveiled, 10-11, 23, 115, 122-123, 142, etc.

65 Besant, Esoteric Christianity, 40, 118, 26o, 275, 292.

66 A scandal where Annie Besant, who took over after Blavatsky as the president of the Theosophical Society, supported the high-ranking member Charles Webster Leadbeater when parts of the society tried to get him ejected following a sex scandal involving young boys. Mead, and many others, left the society in protest when Besant, a close associate of Leadbeater, refused to give him up.

67 Kemp et al, 'Delaire, Jean.' Retrieved 4 April 2020: https://www.oxfordreference.com/view/ 10.1093/acref/978o198117605.001.ooo1/acref-978o1981176o5-e-303. 
an ancient esoteric trend which culminated in Pistis Sophia, foreshadowed already in the Synoptic Gospels. Apocrypha, she argued, were a tradition that had developed this trend and esoteric masters like Basilides and Valentinus were role models to follow. This included the belief in the pre-existence of the soul and the divinity of man in the kinship to God. Gnosticism was not something other than Christianity, but its esoteric current. This was something that could be seen in the canonical writings, too, the point of which was to reach the unveiling of God in man. ${ }^{68}$

The interest in Gnosticism and Pistis Sophia shown by Mead and other Theosophists could be identified as a common way of approaching the study of religion in general, shared by academics and theologians. Theosophists (and many other esoteric groups, as we shall see) viewed Gnosticism as a form of ancient religious knowledge that people had lost touch with, but which was still just one example of a sort of ancient wisdom, a "spiritual truth" that could be found in most traditions if one only looked hard enough. Wouter Hanegraaff has identified what he calls 'ancient wisdom narratives' in western esotericism that developed in the Renaissance as a reaction to newly discovered ancient material. Some saw the re-discovered pagan texts as representations of a pure form of a spiritual truth while others saw them as containing only glimpses of a truth that was being refined to its full potential in the Christian tradition. ${ }^{69}$ As has been argued recently in a study by Johan Nilsson, much the same ancient wisdom narratives can be found in the reception of Chinese religion and the image of "the East" in esoteric milieus, during the latter half of the nineteenth century. As Nilsson has pointed out, the rise of the interest in the eastern ancient wisdom is connected with the discovery of and translations of classical Chinese texts, like The Yijing and Daodejing. ${ }^{70}$

This search for "pure" and "original" forms of religion in preference of "diluted" and "syncretistic" forms of religion also motivated theologians. ${ }^{71}$ This has been studied in detail by, for example, Jonathan Z. Smith, who has identified the same phenomenon among Protestant theologians of the nineteenth century through to the twentieth century. ${ }^{72}$ To some degree, this tendency is still shaping scholarship in religion as early texts are given primacy, "early" being equated with "more true" or more noteworthy. ${ }^{73}$ What Protestant theo-

68 Delaire, 'The "Fifth Gospel".'

69 Hanegraaff, Esotericism and the Academy, 7-12.

70 Nilsson, As a Fire Beneath the Ashes, 67-150.

71 See e.g. Linjamaa, 'Review.'

72 Smith, Drudgery Divine, $1-36$.

73 For a work that problematizes this and the methodology that often guides Bible Studies, see Ehrman, Misquoting Jesus. 
logians in the nineteenth and early twentieth centuries have in common with Europe's esoteric groups is the pursuit of a refined, scaled down, immediate experience of spiritual truth that the established versions of religiosity (for Protestants represented by the Catholic tradition) had either lost touch with or outright kept from the general public. The most obvious Protestant example of this approach to spiritual pursuits can be found in the writings of Henry More, the Protestant theologian who coined the term "Gnosticism" in the first place. He accused Catholics of diluting the pure Christian message by "mixing" it with an overemphasis on rituals and pagan traditions. ${ }^{74}$

For those who believe that neither Catholics nor Protestants had access to the ancient wisdom, these descriptions were hardly interpreted as a negative; on the contrary. There were many esoteric groups in Europe who were rather drawn to the "outsider" perspective. For some, the thought that there was an ancient Gnosis that the church fathers had tried to suppress but which had lived on secretly throughout history in a different guise was appealing. Let us look at some groups and individuals who were not discouraged by Henry More and others, but who felt a kinship with the ancient Gnostics. From there, we can see how they related to Pistis Sophia.

\subsection{The Rise of Gnostic Churches in Europe}

Long before the birth of Theosophy and the work of Mead, Europe had witnessed a gradual growing interest in Gnosticism, particularly among Catholics. In France, a nationalistic form of Catholicism had evolved that did not view the monarch as subordinate to the Pope. This was the French Gallican Church. The influence of Rome and the French monarchy's power over the Church were both being driven back in the aftermath of the French Revolution. ${ }^{75}$ French Ultramontanists, those Catholics still loyal to the Pope and his representatives in France, the bishops of Rome, were driven back, as was the Gallican Church. But even before the Revolution years, there was resistance in France generally toward Rome, not only in the Gallican Church. The French countryside had long witnessed the influence of so-called wandering bishops (episcopi vagantes, which are often not clearly defined) and priests who had been consecrated in ambiguous ways and who had lost touch or been cast out from the Catholic Church (or never been consecrated at all), but who ran churches and

74 King, What is Gnosticism?, 24-54. See also Layton, 'Prolegomena to the Study of Ancient Gnosticism,' 334-340.

75 For an overview of the history of Catholicism in France during the period which this article focuses on, see Gibson, A Social History of French Catholicism. See also Strube, Sozialismus, Katholizismus und Okkultismus. 
congregations around the country regardless, and consecrated anyone whom they themselves saw fit. ${ }^{76}$ This rogue Catholicism was galvanized in the aftermath of the Revolution, which brought with it more religious freedom and disconnection from Rome as well as the Crown. ${ }^{77}$

The life and works of Eugène Vintras (1807-1875) could be seen as embodying these trends. Vintras was a self-proclaimed bishop and claimed to be a reincarnation of the prophet Elijah. He had founded a church in Tilly-sur-Seulles in Normandy, and based his teachings on visions he had received from the archangel Michael, the Virgin Mary, and other figures. Vintras taught people to prepare for the coming of a new age when the Holy Spirit would return. He allowed women to be consecrated as priests and published a periodical called La Voix de la Septaine. Vintras' movement grew as he started to consecrate new bishops into his church, who in turn established new churches in other areas of France. Vintras was later imprisoned on charges of fraud. On his death in 1875, a man named Joseph-Antoine Boullan (1824-1893) declared himself as Vintras' successor. Boullan was a defrocked Catholic priest with strong leanings toward the occult and would develop Vintras' teachings to focus more on sexual symbolism -ideas that are said to have influenced the writings of Huysmans, in particular the occult novel Là-bas. $^{78}$

During this time, Jules Doinel (1842-1903) established the Église Gnostique, the first church in the modern era to take the name of the ancient Gnostics. Doinel, who in his youth aspired to become ordained as a Jesuit, left the seminary and became involved in Freemasonry and Martinism. He was expelled from his lodge in 1895. After having a series of revelations during a séance, he started a new church in order to restore Gnosticism to the world. ${ }^{79} \mathrm{He}$ renamed himself Tau Valentin II, after the famous second-century teacher Valentinus, whose teachings the church fathers had spent so much effort in refuting. Doinel's teachings were based on a mix of Cathar material and ancient Valentinian theology. Just like Vintras, he claimed to have had visions from biblical figures, and the feminine aspect of the divine, and would also allow women to become leaders of his newly established church - principles that were thought to have been practices of the ancient Gnostics before them. Male bishops and

76 Renaud and Brandreth, Episcopi Vagantes; and Anson, Bishops at Large.

77 Pearson, Wicca and the Christian Heritage, 43-58. See Pearson's Chapter 2, 'Churches Gnostic and Agnostic,' in this work for a more detailed overview of the birth of Gnostic churches during this time.

78 Luijk, Children of Lucifer, 164-206; Anson, Bishops at Large, 304; McIntosh, Éliphas Lévi and the French Occult Revival, 188.

79 Pearson, Wicca and the Christian Heritage, 46-47. 
female 'Sophias' were consecrated into his new church, several of whom were famous occult personalities, such as Gérard Encausse, Jean Bricaud, Albert de Pouvourville, and René Guénon. ${ }^{80}$

Encausse, better known as Papus, was a Freemason (like others mentioned above) and one of the founders of the reawakened Martinist order. He had been consecrated as bishop of Toulouse in the Église Gnostique. However, Papus left the Church as he became more involved with Martinism. Papus collaborated with Jean Bricaud, bishop of the Église Gnostique in Lyon, and made Bricaud's version of the Church the main Martinist church, which Bricaud had renamed Église Gnostique Universelle. Bricaud was Boullan's biographer and had previously been involved with Vintras and several other alternative apostolic movements. ${ }^{81}$ Together with Papus, Bricaud made contact with German representatives of the ото, who in turn started their own branch of the Gnostic church, Gnostisch-Katholische Kirche. Aleister Crowley would become the head of the British ото and later named his particular branch of ecclesiastical occultism based on his religion, Thelema, the Ecclesia Gnostica Catholica. ${ }^{82}$

Even though one can observe the interaction between the different Gnostic churches that grew out of the esoteric milieus in Europe during the latter half of the nineteenth and early twentieth centuries, they developed their individual particularities as to the content of the Gnosis they proclaimed and practiced. What they did have in common was the claim of being modern representatives of an ancient form of Gnosticism which mainstream Christianity had come to lose touch with, or directly oppressed. But how did these people and movements relate to the most detailed ancient source on Gnosticism available at the time-Pistis Sophia?

\subsection{The Reception of Pistis Sophia in Early-Twentieth-Century Esoteric Milieus}

Most of the people discussed briefly above certainly knew of Pistis Sophia; some, like Papus, had even studied it in detail. He wrote the book L'âme humaine avant la naissance et après la mort, d'après Pistis Sophia (Paris, 1898), which dealt with questions regarding the nature of the human soul, its origin, and destiny after the death of the body, according to Pistis Sophia. Papus' knowledge of Pistis Sophia was based on the French translation by Amélineau, which Papus criticized due to what he considered a lack of insight into

\footnotetext{
8o Sedgwick, Against the Modern World, 21-72; Toth, 'Gnostic Church,' 400-403.

81 Bricaud, L'Abbe Boullan.

82 Pasi, 'Ordo Templi Orientis,' 898-906. For more on the esoteric milieu in France during this time, see Strube, 'Occultist Identity,' ${ }^{668-595 .}$
} 
the hidden spirituality that was reflected in the text. ${ }^{83}$ Pistis Sophia contained the key to unlocking the meaning of the texts of the Bible which had hitherto been erroneously interpreted, but which the author of Pistis Sophia, Valentinus according to Papus (via Amélineau), presented. After a short ten-page overview of the text, Papus goes on to explain the worldview presented in the text, and the relations between the different levels that the three-plane model consisted of: heaven (Pleroma), an astral plane (which Papus compared to what he called the 'Hermetic dragon' [ouroboros]), and the physical plane where humans live. The human spirit had to learn how to traverse these planes and escape to the Pleroma, guarded by different 'agents of death' (messagers de la mort), which is what Papus called the spiritual beings that were appointed to control the cosmic realm. ${ }^{84}$ Next, Papus describes the nature of humanity, according to his interpretation of the text: a tripartite nature consisting of body, an animated soul, and an immortal spirit. The body was a microcosmos, Papus maintained. ${ }^{85}$ The purpose of the incarnation, Papus writes, was to be initiated into the mysteries and to let the three natures of man return to their origins, as Kabbalah has it. Papus goes on to describe the journey the spirit must undergo according to the text. ${ }^{86}$ In light of his reading of Pistis Sophia, he interpreted passages from the Bible and the role played by key personalities who founded Christianity, like Jesus, Mary, and the twelve apostles. Papus writes that we should not consider them human but that they, as well as the real Christian message, derived from a spiritual plane. ${ }^{87}$ Throughout history, Papus claimed, humanity had been refined through countless rebirths and had now come to a culmination in 'the white race' (la race blanche). Through baptism and initiation into the mysteries, one could escape the cosmic realm. ${ }^{88}$ Papus ends the book by comparing his reading of Pistis Sophia to esoteric teachings of his own time and the 'three stages of evolution.' He sees many similarities to Kabbalah and also criticizes the Catholic Church for suppressing Gnostic teachings and discarding the doctrine of reincarnation which is present in Pistis Sophia. The Hermetic Brotherhood of Light and Freemasons had struggled to keep these traditions in place and develop the knowledge of how to suppress the ego and passions and how to control the physical world through the spirit. ${ }^{89}$

\footnotetext{
83 Encausse, L'âme humaine avant la naissance et après la mort, 8.

84 Encausse, L'âme humaine avant la naissance et après la mort, 25.

85 Encausse, L'âme humaine avant la naissance et après la mort, 31.

86 Encausse L'âme humaine avant la naissance et après la mort, 37.

87 Encausse, L'âme humaine avant la naissance et après la mort, 56 .

88 Encausse, L'âme humaine avant la naissance et après la mort, 58.

89 Encausse, L'âme humaine avant la naissance et après la mort, 83-86.
} 
Papus' disciple, René Guénon, was also interested in ancient Gnosticism, especially in the early period of his esoteric exploits. He became a member of the Église Gnostique and under the name Tau Palingenius he founded the journal La Gnose, which he wrote for until 1922. In the opening number we find a 'Confession of Faith':

- Are you a Gnostic?

- Yes, I am a Gnostic.

- What is Gnosis?

- Gnosis is the enlightened science.

...

- Can you please recite the profession of Faith?

- I confess the doctrine of Emanation and Salvation by Gnosis. ${ }^{90}$

This journal was devoted to the search for Gnosis, defined broadly as spiritual knowledge. Each number began with a list of suggested readings for those who were interested in spiritual knowledge. Here, we find Pistis Sophia mentioned, but the attention it is given in the journal is marginal. One of the few pieces where it is mentioned is found in the second issue published in December 1909. The article is entitled 'Les Sources du Gnosticisme' and it claimed that all the original Gnostic sources were destroyed in the fire of the library of Alexandria, which the Catholics had tried to blame on the Arabs but, in fact, was an act caused by themselves. ${ }^{91}$ The church fathers' depictions are given most attention in the overview of Gnostic sources presented in the article. However, the article does show awareness of the most recent research on Gnosticism at the time, and it does not just take for granted that Pistis Sophia was by the hand of Valentinus, but also cites Schmidt's hypothesis that the text was of Ophite origin. ${ }^{92}$ This is an example of how well-versed esoteric writers were in scholarship. In Papus' book on Pistis Sophia, he even questions whether the version of the manuscript was really the original due to the discrepancies between the four different books the text was made up of. ${ }^{93}$

Even though Pistis Sophia seems to have been well known among specialized esoteric journals and well-read individuals like Papus, there is not much

$90 \quad$ Original: 'Etes-vous Gnostique? Oui, je suis Gnostique. Qu' est-ce que la Gnose? La Gnose est la science illuminative. ... Veuillez reciter la profession de Foi? Je confesse la doctrine de l'Emanation et le Salut par la Gnose' ('Catèchèse gnostique,' 5).

91 'Les Sources du Gnosticisme,' 28.

92 'Les Sources du Gnosticisme,' 3 o.

93 Encausse, L'âme humaine avant la naissance et après la mort, 9. 
to suggest that the text played any major role in the theology or practice of the different Gnostic churches. ${ }^{94}$ In the text Catéchisme Gnostique, written for the Église Gnostique Universelle, one of Papus' disciples and collaborators, Jean Bricaud, formulated the goal of his new church thus:

The goal of the Gnostic Catholic Church is to restore the primitive religious unity, that is, to establish and spread a Christian religion in accordance with the universal religious tradition and the truly Catholic. ${ }^{95}$

Bricaud's Gnostic church, if we take the catechesis as evidence, is hard to separate from the theology of contemporary mainstream churches. The importance of the doctrine of the Trinity (father, son, spirit), transubstantiation, and rituals like baptism, the Eucharist, and anointing are highlighted. Many "Gnostic" terms are used, however. The Pleroma, gnosis, and the archons are frequently mentioned, for example, but it is unclear in what sense these terms differ from the Catholic or Protestant notion of God, heaven, and evil spirits. Pistis Sophia and other Gnostic sources are not discussed or quoted in Bricaud's catechesis and did not seem to have had much influence on the teachings of Église Gnostique Universelle.

Let us move finally to the German-speaking part of Europe. GnostischKatholische Kirche was founded by members of the German esoteric milieu after they had established contact with Bricaud and Papus during the beginning of the twentieth century. Theodor Reuss, who, together with Carl Kellner, had started the Masonic inspired order ото, made the Gnostisch-Katholische Kirche, or the Ecclesia Gnostica Catholica as it is better known, their ecclesiastical branch. Papus and Bricaud were given high ranks in the ото and Reuss was consecrated as the Swiss representative of Église Gnostique Universelle by Bricaud. ${ }^{96}$ In 1912, Reuss appointed Aleister Crowley as the head of the British ото and together they developed the system that came to be the order's ritual features, involving a focus on sexual magic, which diverged much from what

94 One aspect that might have been inspired by Pistis Sophia is the focus on the dialogueform of presenting the message of "Gnosis". Bricaud and Guenon both used it when presenting their message. This is also present in Pistis Sophia, but is hardly unique, so whether this was inspired by the text is hard to know.

95 Original: L'Eglise catholique gnostique a pour but, essentiel de restituer l'unité primitive religieuse, c'est-a-dire d'établir et de répandre une Religion chrétienne conforme a la tradition religieuse universelle et par la véritablement catholique (Bricaud, Catéchisme Gnostique, 47).

96 Pasi, 'Ordo Templi Orientis,' 899-902. 
we know was the focus in the different Gnostic churches in France, although there is some overlap (for example, the supposed interests of Boullan). ${ }^{97}$

Pistis Sophia seldom had any central role in the theology and ritual life developed in these different esoteric milieus claiming a Gnostic heritage; in fact, it was rarely discussed in any great depth. One exception, apart from Papus who studied the text in detail, is the representative for the Latin American branch of the ото, the leadership of which Reuss had given to Arnold Krumm-Heller. As Franz Winter has previously noted, Krumm-Heller, a doctor, naval officer and prolific writer, held Pistis Sophia in very high regard and named it a holy book. ${ }^{98}$ Pistis Sophia was for Gnostics what the Talmud was for the Jews, what the Bhagavad-Gìtā was for Hindus, the Qurān for Muslims. ${ }^{99}$ He would leave the ото and start his own Gnostic church that featured a journal, Rosa Cruz, where articles were published on many esoteric topics, particularly Gnosticism. It remained active until 1985. Krumm-Heller was acquainted with Crowley and also developed an interest in similar sexual rites as those Crowley composed in Liber $X V$, or 'the Gnostic Mass,' which became the liturgical bedrock of Ecclesia Gnostica Catholica. ${ }^{100}$ However, Krumm-Heller complained that the many Gnostic churches that had appeared during his life were in fact little acquainted with the ancient Gnostic material with which they claimed kinship. KrummHeller was extremely productive, mostly in his adopted language Spanish, and in the introduction to his book Iglesia Gnostica he wrote the following about other Gnostic churches:

They have not read these works, nobody has studied Gnosis, they have celebrated the Gnostic Mass with the same routine as they do in other churches. In Brazil a journal was published (by Brazilian Gnostics) without any article dealing with Gnosis in its hidden part and therefore they do not deserve the name they bear. So today, as this book is published

97 For more on Boullan, see Luijk, Children of Lucifer, ${ }^{175}-185$. It is unclear, however, what exactly Reuss meant by sexual magic. Crowley's ideas are much more studied and straightforward. Pasi, 'Ordo Templi Orientis,' 902. For more on sexual magic and Reuss, see Urban, 'The Knowing of Knowing,' 99-116.

98 Krumm-Heller, La Iglesia Gnostica, 13. Winter, 'Studying the "Gnostic Bible", 98. Winter does not engage the question of how Krumm-Heller implemented the text in his teachings. Winter is most likely right that Samael Aun Weor was inspired by Krumm-Heller in his reading of Pistis Sophia, because he and Krumm-Heller both seem to view Gnosticism as a kind of "sexual mysticism" which leads to prolonged life as well as spiritual growth.

99 Krumm-Heller, La Iglesia Gnostica, 4. As Winter has noticed, Krumm-Heller attributes the Bhagavad-Gìtā to 'los budistas.' I have corrected this above.

100 I am not claiming that Krumm-Heller drew on Crowley's work or vice versa. 
again, I beg the readers not to read it superficially, but to repeat the reading several times, to study the mentioned literature and then ask me about the rites, only then will we have (access to) the first Gnostics that until now, it pains me to confess, I am alone (in understanding), and if this situation does not change, I will not allow another edition to be published. So, supporters of Hermetic studies know what they have to do. If we achieve something that penetrates the mysteries, I will be satisfied and I will be happy. Forward ... forward ... ${ }^{101}$

Krumm-Heller begins his book by presenting a well-informed introduction to the scholarship on Pistis Sophia. He is aware of the fact, as Papus was, that the four different "books" that Pistis Sophia is made up of do not represent parts of an originally composed whole. He writes that the foundation of the work is most likely an Ophite production and emphasizes the importance of reading the ancient material within its own context if one seeks to understand the text. He then presents a short overview of the text's contents, and concludes that what the scholars have written is insufficient since they lack the keys to understanding the deeper meaning of the text, which demands initiation. ${ }^{102}$ Thus, while it is true that the Pistis Sophia known to most people in its Coptic variant-a piecemeal production — does not reflect a straight-forward message of spiritual enlightenment, the original Greek work did, and this message was safeguarded by Iglesia Gnostica. Krumm-Heller had managed to interpret the hidden meanings behind the text, and much of what he found there was occupied with harnessing the human sexual drive and sexual secretions. The Catholic Church had, Krumm-Heller maintained, thrust upon people an unhealthy strive for celibacy — which, as he writes, only one in a hundred thousand priests ever manage to uphold. Instead, one should harness the positive attributes of sex and transform it to prolong one's life and grow one's intellec-

101 Original: No han leído estas obras, nadie ha estudiado la Gnosis, han celebrado la Misa Gnóstica con la misma rutina como lo hacen en las demás iglesias. En Brasil han publicado una Revista pero ningún artículo que trate de Gnosis en su parte oculta y por está no merece el nombre que lleva. Así que hoy, que vuelva a salir este libro, yo les suplico a los lectores no lo lean superficialmente, sino que repitan la lectura varias veces, que estudien la literatura mencionada y luego me pidan prácticas, solo entonces tendremos los primeros Gnósticos que hasta ahora, pena me da confesarlo, estoy solo y si no cambia está situación, no vuelvo a permitir que se publique otra edición. Así que los aficionados a los estudios herméticos saben lo que hacen. Conque logremos algunos que penetren en los misterios, me daré por satisfecho y estaré contento. Así que adelante ... Adelante ... (Krumm-Heller, La Iglesia Gnostica, 1).

102 Krumm-Heller, La Iglesia Gnostica, 6. 
tual power. The Gnostic Church could help people develop these skills. ${ }^{103}$ It is unclear what passages of the Pistis Sophia, the 'Gnostic Bible,' Krumm-Heller used to support this view of sex as the way to enlightenment.

Krumm-Heller's approach to Pistis Sophia resembles those of other esoteric groups and individuals. Like Papus and Theosophists, like Blavatsky and Besant, he claimed to have the key to unlocking the hidden meaning of the text. In its present state the text was beyond scholars and other religious groups; it was only accessible through their specific version of the ways to access spiritual truth. Just like Papus, and many Theosophists, Krumm-Heller put emphasis on the evolutionary aspect of human ability to access spiritual truth. The newly developed race of light, however, welcomes both sexes, all nations, and creeds. ${ }^{104}$ The hidden spiritual knowledge offered in Gnosticism was for a spiritual elite, a view that many ancient Christians had developed in light of the writings of the Apostle Paul. In First Corinthians, Paul wrote that psychic humans lacked deeper understanding while a spiritual race of people were those who could discern all things, because they have 'the spirit that is of God'

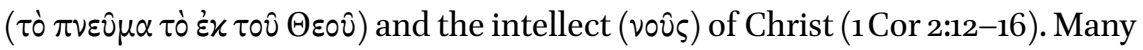
Gnostic Christians, in particular Valentinians, highlighted and further developed these ideas, some of which found their way into texts like Pistis Sophia. ${ }^{105}$ These aspects of Gnostic writings spoke to the exclusive image maintained in many esoteric circles.

However, there were other aspects of ancient Gnosticism that were picked up in esoteric circles which were less supported by historical evidence. Some were even picked up in direct opposition to what one could read in Pistis Sophia. Let us move the discussion about Pistis Sophia and Gnosticism in general to include those aspects that were ignored. This will lead us to the final discussion regarding how Gnosticism was actually imagined in western esotericism, and how it related to views in academia, then and today.

\footnotetext{
103 Krumm-Heller, La Iglesia Gnostica, 40.

104 Krumm-Heller, La Iglesia Gnostica, 2.

105 This has been discussed at length by many scholars. See, for example, Dunderberg, Beyond Gnosticism, passim; Dunderberg, Gnostic Morality Revisited, 137-148; Linjamaa, The Ethics of The Tripartite Tractate, $159-185$.
} 


\section{From Esoteric Milieus to Contemporary Academia}

\subsection{The Image of Gnosticism as Counterculture}

Even though Pistis Sophia is seldom mentioned and its specific theology given little precedence in the doctrines developed by Gnostic churches and occultist groups, its mere existence inspired people drawn to esoteric milieus. Scholarly writings on Gnosticism were probably more accessible than the long and dense Pistis Sophia. Charles William King's book on Gnosticism was frequently mentioned and recommended, and his work on ancient gems and particularly those associated with Gnosticism - featuring Abraxas, Ialdabaoth, and other ancient demiurgic figures and spells_-were most likely inspirational for key esoteric figures like Eliphas Lévi, Crowley, and others who came to adopt zoomorphic figures (like Baphomet), similar to those we see on ancient gems, as symbols of occult wisdom.

It is clear, nevertheless, that esoterically interested individuals and organizations in the present survey were more inspired by the depictions of ancient Gnostics appearing in the writings of the church fathers. And it was the aspects that were considered unorthodox by the mainstream that were emphasized, e.g. stories that presented ancient Gnostics as granting high status to women and the feminine, how Valentinians and other Gnostics performed mock marriages to angels, numerological speculation, the use of talismans, and alchemical and gematrical manipulations in order to gain access to a secret knowledge. Little of this, however, is reflected in Pistis Sophia.

One of the most infamous depictions of Gnostic rites from antiquity is preserved in the writings of Epiphanius. He wrote that a group he was familiar with performed versions of the Eucharist where they consumed blood and semen instead of wine and bread. 106 The more extravagant and excessive depictions, often born out of polemics, are given an unprecedented amount of attention in the revival of Gnosticism in Europe, from esoteric groups to academics alike. Esoteric groups and Gnostic churches emphasized the importance of the feminine: Doinel is said to have been visited and guided by Sophia (Wisdom); Boullan taught and performed marriages between his congregants and divine angelic beings; Reuss' and Krumm-Heller's interest in sexual magic, not to mention Aleister Crowley's rituals developed in Liber XV, very much resembled the Gnostic rituals described by Epiphanius and other polemical exaggerations but are in fact seldom (or never) encountered in the first-hand Gnostic material.

106 Epiphanius, Panarion 1.26; Irenaeus, Against Heresies I. 
However, as already suggested by Michael Williams in 1996, and as I have recently expanded upon, there is little that supports the fact that these extreme versions of the rituals Epiphanius described were actually performed by any religious groups in antiquity. ${ }^{107}$ References to sexual rituals such as those described by Epiphanius, for example, not to mention the cannibalism and murder of children, ${ }^{108}$ are not found in any of the ancient Gnostic sources. This is true save for two exceptions, one of them being Pistis Sophia. In book IV of Pistis Sophia a semen ritual is mentioned. However, it is vehemently rejected as the worst sort of heretic activity. ${ }^{109}$ These forms of rituals, even though they came to be performed symbolically or in other modified ways among some modern occult groups associated with Gnosticism, rather fit into archetypal ways of slandering "the other" - activities that were always attached to someone else. Most of the detailed studies of Pistis Sophia among the esoteric individuals and academics discussed above overlooked the fact that the text actually rejected the very rite that Epiphanius claimed defined Gnostics. The only exception I have found is Mead. He acknowledges it but does not spend any time on the issue, but neither did his view of Gnosticism involve ritual practice where human bodily fluids were consumed. ${ }^{110}$

It is not surprising that these perspectives of identity creation and the rhetoric of heresiology were not generally part of the perspective that academics and esoteric milieus of nineteenth- and early twentieth-century Europe approached Gnosticism with. However, the idea of what Gnosticism is thought to represent is so strong that even contemporary scholars still treated the evidence of Epiphanius as reflecting part of what Gnosticism is thought to be, even though we still lack Gnostic texts from antiquity describing these rites as anything other than objectionable. ${ }^{111}$

Attempts have been made to rehabilitate the view of Gnostics as amoral libertines. In a recent article by Dylan Burns, the sexual imagery appearing in the mythological world of the Nag Hammadi text Paraphrase of Shem is expounded upon. Burns writes that because the text sees 'the demiurge as a "womb," divine

107 Williams, Rethinking "Gnosticism", 179-184; Linjamaa, '"Mocked by the Archon of Lust", 316-334. Similar findings have been concluded by Johannes van Oort concerning the "ritual of the fig" among Manichaeans, who were accused of dipping the fig in human semen during a ritual. See, Oort, 'Another Case of Human Semen Eucharist,' 430-440.

108 Epiphanius, Panarion 1.26.

109 Pistis Sophia 4.147, see also The Books of Jeu 2.43 where a similar ritual is rejected.

110 Mead, Pistis Sophia, $\mathrm{x}-\mathrm{xxx}$.

111 See, for example, Gero, 'With Walter Bauer on the Tigris,' 287-307; Benko, 'The Libertine Gnostic Sect of the Phibionites,' 103-119; but more recently, Broek, 'Sexuality and Sexual Symbolism,' 1-22; DeConick, Holy Misogyny, 106-110. 
intervention in creation as a seduction of the demiurge, salvation history as the emptying of divine light from the world, human reproduction as demonic activity, and the elect as Sodomites,' it could indicate that the text supports 'the veracity of the heresiographers' claim that such transgressive ideas circulated amongst some of their contemporaries.' ${ }^{112}$ Burns seeks to reevaluates the term 'libertine' that has in the last decades been disregarded to a large extent as a polemical invention. However, here, too, the engagement of ritual sexual activity are actually rejected in Paraphrase of Shem and applied to "someone else," i.e., heretics. ${ }^{113}$

Burns' attempt to revisit the libertine-concept in order to enable the ancient sources to be interpreted more broadly represents one of the more balanced approaches to ancient sexual libertinism. Others have gone further and simply read Epiphanius' reports or statements as historical facts. ${ }^{114}$ In a newly published article on the portrayal of Mary Magdalene in "Gnostic" texts, Cambry Pardee writes that Epiphanius was prone to 'uncharitable and biased recollections,' but in the very next passage presents the semen and menses rituals Epiphanius describes as credible, even 'sensible to some Gnostic groups.'115 However, the fact remains that Epiphanius' statements are not supported by first-hand sources, but rather follow common polemical patterns and rhetorical strategies that go back to how Romans used to describe Christians. ${ }^{116}$ These rhetorical strategies were then taken over by Christians (on both sides of orthodoxy) and applied to other Christians who were considered theologically deviant in some way. The church fathers' depictions of Gnostics struck a chord with what Hanegraaff has called the 'ancient wisdom narratives' that developed from the Renaissance on, as ancient texts were rediscovered and reintroduced. There was a deeper spiritual truth hidden behind the existing religions. The discovery of Pistis Sophia inspired many to seek this truth in Gnosticism, even though it did not really reflect what people associated with the phenomenon: sexual libertinism. Before concluding this study, let us look at

112 Burns, 'Gnosis Undomesticated,' 151.

113 See Paraphase of Shem NHC VII,1 4.29-32, 14.13-16, 18.31-35, 21.30-36, 22.5-9, 23.22-24. Burns is, of course, aware of this but nevertheless argues that viewing the existence of libertine Gnostics is historical sound, in light of the mythical language of the text that uses sexually saturated images and language.

114 See note 113 .

115 Pardee, 'The Gnostic Magdalene,' $65^{-66 .}$

116 For more on this line of argument, see Linjamaa, '"Mocked by the Archon of Lust", 316334. And as Williams showed in 1996, the division of ancient Gnostics as either bodyhating ascetics or promiscuous libertines was mostly based on polemically inspired structures. 
one more example of a phenomenon erroneously associated with Gnosticism and how it, along with (or through) the ancient wisdom narrative has been spurred on by the discovery of new texts.

\subsection{Ancient Wisdom Narrative Revived: The View of Gnostics as Feminists in Contemporary Academia}

The reception of Pistis Sophia, and Gnosticism more broadly, in European esoteric circles was deeply colored by the religious anticipations and fervors of the time- a time that saw the beginning of female liberation and religious emancipation. Gnostics were seen as ancient representatives of similar struggles against conformity, an ancient counterculture movement. As we have seen, esoteric groups and academics alike have long associated Gnostics with libertine behavior, and still do, to a certain extent. Another heresiological exaggeration that was to inspire esoteric groups and academics alike in their view of Gnosticism - even more than viewing Gnostics as sexually progressive-was gender equality. Many church fathers portrayed Gnostics as positive toward female leadership and the image of the feminine in general. However, just like libertine behavior, it was not uncommon that femininity was used as a slander against one's enemies. As the philosopher Celsus wrote about Christians in general, only silly women and children would follow the Christians. ${ }^{117}$ The same argument was picked up by Christians themselves and applied to "heretics". Tertullian wrote that the Gnostic groups he knew would be interesting solely for women, because there they were allowed to run free. ${ }^{118}$ Even though Pistis Sophia, like some other ancient texts, gives a prominent role to Mary Magdalene, there is not much to support the view that Gnostic groups in antiquity were progressive communities regarding their view on gender roles in any higher degree than other Christian communities, nor that they held the symbol of the feminine in higher regard compared to other Christian groups. We find just as much misogynic material in so-called Gnostic texts as in protoorthodox material, ${ }^{119}$ and just as much praise for femininity and womanhood in proto-orthodox material as in so-called Gnostic material. ${ }^{120}$

Nevertheless, the church fathers' attempts to slander Gnostics are still taken at face value. As we have seen above, with the French Gnostic churches and

\footnotetext{
117 Origen, Against Celsus III.44.

118 Tertullian, De praescriptione 41-44.

119 For just a few examples, see The Tripartite Tractate (NHC I): 94:17-18, 78:8-13; Eugnostos the Blessed (NHC III): 85:3-9, (NHC v): 13:1-7; The Wisdom of Jesus Christ (Papyrus Berolinensis 8502): 107:8-108:1; Gospel of Thomas (NHC II), logion 114.

120 See Wisse, 'Flee Femininity,' 297-307.
} 
others, gender equality within the church was thought to be a key ingredient in Gnosticism. This is not unique for the view of Gnosticism in esoteric milieus of nineteenth- and early twentieth-century Europe; it is an idea that still prevails in esoteric circles, as well as in modern academia. And yet, again, the idea that there existed a progressive religious current (in this case identified with Gnosticism) which the majority of religions have tried to suppress since antiquity was inspired by newly discovered ancient sources. The Nag Hammadi texts were discovered in 1945 and translated a few decades later, generating a new scholarly surge and popular interest in Gnosticism. A plethora of Gnostic churches around the world draw inspiration from these texts, associated with a secret form of Christianity believed to have been intentionally suppressed by the Church and the governing patriarchal systems that have been in place since ancient times. Similar trends are clearly visible in modern scholarship, too. In her immensely popular book The Gnostic Gospels from 1979, Elaine Pagels argued that 'the Gnostics' had rejected the patriarchal structures that sought to limit access to the divine. She wrote that 'in 1977, Pope Paul VI, Bishop of Rome, declared that a woman cannot be a priest "because our Lord was a man"! The Nag Hammadi sources, discovered at a time of contemporary social crises concerning sexual roles, challenge us to reinterpret history-and to reevaluate the present situation.' ${ }^{\prime 21}$ Gnostics were, Pagels maintained, ancients who had sought knowledge of God first hand, who had given women leadership positions, and who viewed the feminine on a par with the male God of the Hebrew Bible. ${ }^{122}$ Pagels is not the only scholar personally inspired by the Nag Hammadi-texts, attempting to make them reverberate in contemporary social and political issues, influenced by what seems to be a similar ancient wisdom narrative as those popular among esoteric groups and individuals claiming a Gnostic heritage studied above. In a fairly recent book, The Gnostic New Age, April DeConick gave her own view about the sources that have guided much of her scholarly quests:

For years I had been searching for a spiritual church home. I had visited just about every Christian denomination under the sun. But I always left their services disappointed and disenchanted. The God of goodness and providence that I knew from my personal religious life did not seem to be present in any of the traditional Christian churches I attended. No matter how hard I tried, I could not harmonize the God of unconditional love

121 Pagels, The Gnostic Gospels, 69.

122 Pagels, The Gnostic Gospels, 48-69. 
I personally knew with the conventional Christian God who demanded that his son be sacrificed to him for the salvation of sinful human souls. It wasn't until I read the Gospel of Thomas that I felt aligned with Christianity. ${ }^{123}$

DeConick goes on to present a hypothesis that what she has found in the ancient Gnostic material is a kind of countercultural spirit which has been extant in human culture throughout most of human history, but suppressed by the powers that be, governed by patriarchal structures. This countercultural spirituality seeks immediate access to the divine. It is esoteric but, at the same time, open to all. It is an intellectual journey but one that affirms human emotional life. The ancient Gnostics manifested this religion and stood up against the oppressive structures of leading male dominated elites. ${ }^{124}$

The most recent work that presents Gnosticism as a timeless countercultural movement is found in the work of Jonathan Cahana-Blum. He suggests that what we see in Gnostic texts and mythology represents a form of critique against social order in antiquity, including roles pertaining to sexuality and gender. ${ }^{125} \mathrm{He}$ has, for example, argued that the portrayal of androgyne figures in gnostic myths - that God is called Mother-Father or the 'thrice great androgyne'126 —is a reflection of the "Gnostic" critique of ancient gender roles. ${ }^{127}$ This is, Cahana-Blum writes, 'in line with [Judith] Butler's own purpose,' 'done in order to underline how constructed the normative concepts of gender are.'128 Instead of reading these gender transcending categories one sometimes encounters in Gnostic myths - and it must be added, in other ancient religious traditions, too (for androgyne mythic figures is far from unique to Gnosticism!) — in light of ancient views on gender, the modern discourse of gender and queer theory is forced onto a context that is wholly alien to it. There are no sources that indicate that Gnostics protested ancient gender roles in society. Myths cannot be read (without clear qualifications)

123 DeConick, The Gnostic New Age, 1-2.

124 David G. Robertson has previously critiqued DeConick's approach and depiction to Gnosticism and described it as an Eliadian take on religion, where Gnosticism is viewed as a sort of ahistoric phenomena in line with C.G. Jung's view of the concept. Robertson, 'A Gnostic History of Religions,' 75-88. See also the recent monograph Robertson, Gnosticism and the History of Religions, which arrived while the present article was already in production.

125 Cahana-Blum, Wrestling with Archons, 3, 65-126.

126 Apocryphon of John (NHC II) 12.1-8.

127 Cahana, 'Androgyne or Undrogyne?', 509-524.

128 Cahana, 'Androgyne or Undrogyne?', 521. 
as reflecting social reality, especially an anachronistic version of social reality. "Gnostics," along with many other religious and philosophical currents in antiquity, sought to transcend the limits of materiality (of which gender was a symbol), not overthrow cis-normativity. This view of Gnosticism-that it represents an ancient progressive movement which curiously enough resembles recent struggles for equality and postmodern discourses reevaluating societal norms - can be found in esoteric and academic circles alike.

As Karen King and Petter Spjut have argued, the reception of Pistis Sophia among Europe's theologians was guided by preconceived notions of what Gnosticism was thought to be. To a large extent, the text was discarded due to what was understood as a discrepancy with "Gnostic" characteristics. The same conclusion cannot be drawn from the broad survey above of the esoteric milieus of Europe in the late nineteenth and early twentieth centuries. Many esoteric authors recognized Pistis Sophia as an important text, hailing it as a source of great wisdom. Even though many who had studied the text in detail were aware that the text had most likely been subjected to editorial work already in antiquity, and thus was not "pure" or "original," the text was not simply discarded as a diluted form of a once pure Gnosticism. However, the content was often read in light of an already established esoteric trajectory, for example Blavatsky's, Krumm-Heller's, or Papus' particular spiritual evolutionary perspectives. In fact, that the text had been edited in antiquity gave esoteric readers the perfect excuse to fit it into their own idea of what Gnosticism had really been about.

Pistis Sophia generated interest among esoteric groups because it was a representation of the ancient wisdom narrative, a universal religion of which Gnosticism was a powerful manifestation. It was part of a religious tradition that had conserved the hidden truth in face of conventionality. I argue that this way of viewing Gnosticism is not just an esoteric phenomenon, but is found in contemporary academia as well. Reading Gnosticism as preserved secret teachings, with a countercultural bent, gained influence in the wake of the discoveries of new ancient "Gnostic" texts, such as at Nag Hammadi. These views of Gnosticism are, I argue, built on the constructions of the church fathers and their polemics. As Karen King and Michael Williams have pointed out, Gnosticism is the very essence of "the other". Nevertheless, scholars still portray "Gnostics" — in my mind, without convincing basis in first-hand sources—as representing a progressive agenda, comprising gender equality and sexual lib- 
ertinism. ${ }^{129}$ I hope to have demonstrated that there are very close association between esoteric and academic approaches toward Gnosticism. It would seem that scholars and modern practitioners of "Gnosticism" are often part of the same trajectory— that of seeking Gnosticism's true "religious essence," treating it as a phenomenon that has somehow transcended the historical context of the sources.

\section{Acknowledgments}

The work behind this article was generously funded by the Crafoord Foundation, and represents parts of the results of the postdoc project "The Reception of Pistis Sophia", hosted by Lund University 2018-2019

\section{Bibliography}

\section{Ancient Primary Sources}

Epiphanius. Panarion. Translated by Franciscus Oehler, Epiphanii, Episcopi Constantiensis. Panaria. Berlin: Asher et Socios 1859.

Eugnostos the Blessed. Edited by Douglas M. Parrott, Nag Hammadi Codices III,3-4 and V,r. Leiden, Brill 1991.

Irenaeus. Against Heresies. Edited by W. Wigan Harvey, 2 vols. Rochester: St. Irenaeus Press 2013.

Origen. Against Celsus. Edited by Marcel Borret, 4 vols., Paris: Cerf 1967-1969.

Pistis Sophia. Edited by Carl Schmidt, translated by Violet MacDermot. Leiden: Brill 1978.

Tertullian. De praescriptione. Translated by Alexander Roberts, in Ante-Nicene Fathers, vol. 3, eds. Alexander Roberts, A. Cleveland Coxe, and James Donaldson. Buffalo, NY: Christian Literature Publishing Co. 1885.

The Books of Jeu. Edited by Carl Schmidt, translated by Violet MacDermot. Leiden: Brill 1978.

The Gospel of Thomas. Edited by Bentley Layton and translated by Thomas O. Lambdin, Nag Hammadi Codices II,2-7. Leiden, Brill 1991.

129 With this "countercultural" perspective of Gnosticism, one is liable to overlook those, ancient as well as modern, who identified as Gnostics but who did not fit the countercultural mold, as Clement of Alexandria in antiquity or Bricaud's Église Gnostique Universelle. 
The Tripartite Tractate. Edited and translated by Harold W. Attridge and Elaine Pagels, in Nag Hammadi Codex I (The Jung Codex): Introduction, Text, Translation, Indices, ed. Harold W. Attridge. Leiden: Brill 1985.

The Wisdom of Jesus Christ. Edited and translated by Douglas M. Parrott, Nag Hammadi Codices III,3-4 and V,ı. Leiden: Brill 1991.

\section{Modern Primary Sources}

Amélineau, Émile. Pistis-Sophia: ouvrage gnostique de Valentin. Paris: Chamuel, 1885.

Annie Besant. Esoteric Christianity: Or, The Lesser Mysteries. Wheaton: Quest Books, 2006 [1898].

Blavatsky, H.P. Isis Unveiled. New York: Theosophical Society, 2006 [1887].

Bricaud, Johannes. Catéchisme Gnostique. Lyon 1907.

Bulhe, J.G. Literarischer Briefwechsel von Joham David Michaelis, 3 vols. Leipzig 17941796.

Bultmann, Rudolf. 'Points of Contact and Conflict,' in Rudolf Bultmann. Essays: Philosophical and Theological. London: SCM Press 1955, 133-150.

Bunsen, Christian Charles Josias. Hippolytus and His Age, or the Beginnings and Prospects of Christianity. London: Longman, Brown, Green, and Longmans 1854.

'Catèchèse gnostique: publiée par Mandement de sa Grâce le Patriarche et par L' Ordre du Très-Haut Synode,'La Gnose 1:1 (1909): 5-6, ed. Guenon, René. Paris.

Cramer, J.A. Beyträge zur Beförderung theologischer und anderer wichtigen Kenntnisse. Kiel \& Hamburg: Carl Ernst Bohn 1778.

Delaire, Jean. 'The "Fifth Gospel”, The Occult Review 61:1 (1935): 166-172.

Dulaurier, E. 'Notice sur le Manuscript copte-thébain, institulé La Fidèle Sagesse; et sur la Pulication projetée du Texte et de la Traduction francaise de ce Manuscript,' Journal Asiatique, Quatrième Série, Tome ix (1847): 534-548.

Encausse, Gérard. L'âme humaine avant la naissance et après la mort. Paris: Chamule, 1898.

Harnack, Adolf von. Über das gnostische Buch Pistis-Sophia. Texte und Untersuchungen zur Geschichte der altchristlichen Literatur 7.2. Leipzig: J.C. Hinrichs'sche Buchhandlung, 1891.

Harnack, Adolf von. History of Dogma I. New York: Dover 1961.

King, C.W. The Gnostics and their Remains: Ancient and Mediceval. London: David Nutt, 1887.

Krumm-Heller, Arnold. La Iglesia Gnostica. Buenos Aires: Buenos Aires Press, 1985 [1931].

von Köstlin, K.R. 'Das gnostische System des Buches Pistis Sophia,' in Theologische Jahrbücher 13, eds. Baur \& Zeller. Tübingen 1954.

'Les Sources du Gnosticisme,'La Gnose 1:2 (1909): 28-31, ed. Guenon, René. Paris.

Lucifer 4, 6, eds. H.P. Blavatsky \& M. Collins. London 1887, 1890. 
Mead, G.R.S. Pistis Sophia: A Gnostic Gospel (With Extracts from the Books of the Saviour Appended). London: The Theosophical Publishing Society 1896.

Mead, G.R.S. 'Pistis Sophia', Lucifer 6:32 (189o): 107-113.

Münter, Fredrich. Odae Gnosticae Salomoni tributae, thebaice et latine, praefatione et adnotationibus philologicis illustratae. Copenhagen: Schultz 1812, 1-32.

Reitzenstein, Richard. Die hellenistischen Mysterienreligionen: nach ihren Grundgedanken und Wirkungen. Leipzig: B.G. Teubner 1910.

'Review: The Gnostics and their Remains', Lucifer 4 (1887): 332-334.

Schmidt, Carl. Koptisch-gnostische Schriften, Bd. ı: Die Pistis Sophia. Die beiden Bücher des Jeu. Unbekanntes altgnostische Werk 2. Die Griechischen Christlichen Schriftsteller der ersten drei Jahrhunderte, vol. 13. Leipzig:J.C. Hinrichs'sche Buchhandlung 1905 .

Schmidt, Carl. Pistis Sophia: Ein Gnostisches Originalwerk. Leipzig: J.C. Hinrichs'sche Buchhandlung 1925 .

Schwartze, Moritz Gotthilf. Pistis Sophia: opus gnosticum Valentino adiudicatum e codice manuscripto coptico Londinensi descriptum, ed. J.H. Petermann. Berlin: Ferdinand Dümmler 1851.

The Occult Review 61:1, 'The London Forum,' ed. Unknown. London: Rider \& Co., Paternoster House 1935 .

Woide, Gottfried. 'Fragmenta Novi Testamenti juxta interpretationem Dialecti Superioris Aegypti quae Thebaidica maxima ex parte Desumpta, cum Dissertatione de Versione Bibliorum AEgyptica quibus subjictur Codicis Vaticani Collation,' Appendix ad Editionem Novi Testamenti Graeci e Codice MS Alexandrino. Oxford 1799.

\section{Secondary Sources}

Anson, Peter F. Bishops at Large: Some Autocephalous Churches of the Past Hundred Years and their Founders. London: Faber \& Faber 1964.

Azize, Joseph. 'Assessing Borrowing: The Case of Gurdjieff,' Aries 20 (2020): 1-30.

Azize, Joseph, 'Churton, Deconstructing Gurdjieff,' June 30, 2017, http://www.josephazi ze.com Accessed April 6, 2020: http://www.josephazize.com/2017/o6/3o/churton -deconstructing-gurdjieff/

Benko, Stephen. 'The Libertine Gnostic Sect of the Phibionites,' Vigiliae Christianae 21 (1967): 103-119.

Brakke, David. The Gnostics. Cambridge, MA: Harvard University Press 2010.

Broek, Roelof van den. 'Sexuality and Sexual Symbolism in Hermetic and Gnostic Thought and Practice (Second-Fourth Centuries),' in Hidden Intercourse, eds. W.J. Hanegraaff and J. Kripal. New York: Fordham University Press 2011, 1-22.

Bull, Christian. The Tradition of Hermes Trismegistus: The Egyptian Priestly Figure as a Teacher of Hellenized Wisdom. Leiden: Brill 2018.

Burns, Dylan. 'Gnosis Undomesticated: Archon-Seduction, Demon Sex, and Sodomites in the Paraphrase of Shem (NHC VII,1),' Gnosis 1 (2016): 132-156. 
Burns, Dylan. 'Weren't early Christians up against a gnostic religion?,' in Hermes Explains: Thirty Questions about Western Esotericism, eds. W. Hanegraaff, P.J. Forshaw, and M. Pasi. Amsterdam: Amsterdam University Press 2019, 61-69.

Cahana, Jonathan. 'Androgyne or Undrogyne?: Queering the Gnostic Myth,' Numen 61 (2014): 509-524.

Cahana-Blum. Jonathan, Wrestling with Archons: Gnosticism as a Critical Theory of Culture. Lanham: Lexington Books 2019.

Churton, Tobias. Deconstructing Gurdjieff: Biography of a Spiritual Magician. Rochester: Inner Traditions International 2017.

Crégheur, Eric. 'En amont de la découverte de Nag Hammadi: Nouvelle traduction française et concordance de la Pistis Sophia du codex Askew (British Library Additional 5114),' Ancient Judaism 4 (2016): 217-233.

Crégheur, Eric. Les “deux Livres de Iéou” (MS Bruce 96, 1-3), Bibliothèque Copte de Nag Hammadi Section 'Textes,' 38. Leuven: Peeters 2019.

DeConick, April. Holy Misogyny: Why the Sex and Gender Conflicts in the Early Church Still Matters. New York: Bloomsbury 2013.

DeConick, April. The Gnostic New Age: How a Countercultural Spirituality Revolutionized Religion from Antiquity to Today. New York: Columbia 2016.

Dunderberg, Ismo. Beyond Gnosticism: Myth, Lifestyle, and Society in the School of Valentinus. New York: Columbia University Press 2008.

Dunderberg, Ismo. Gnostic Morality Revisited. Tübingen: Mohr Siebeck 2015.

Ehrman, Bart. Misquoting Jesus: The Story Behind Who Changed the Bible and Why. San Francisco: HarperSanFrancisco 2005.

Evans, Erin. The Books of Jeu and the Pistis Sophia as Handbooks to Eternity: Exploring the Gnostic Mysteries to the Ineffable. Leiden: Brill 2015.

Faivre, Antoine. Access to Western Esotericism. New York: sunY Press 1994.

Gero, Stephen. 'With Walter Bauer on the Tigris: Encratite Orthodox and Libertine Heresy in Syro-Mesopotamian Christianity,' in Nag Hammadi Gnosticism and Early Christianity, eds. C.W. Hedricks and R. Hodgson. Peabody, MA: Hendrickson 1986, 287-307.

Gibson, Ralph. A Social History of French Catholicism, 1789-1914. London: Routledge 1989 .

Hanegraaff, Wouter. Esotericism and the Academy: Rejected Knowledge in Western Culture. Cambridge: Cambridge University Press 2012.

Hanegraaff, Wouter. Western Esotericism: A guide for the Perplexed. London: Routledge 2013.

Johnston, Steve. 'Proximité littéraire entre les codices Askew et Bruce,'Journal of Coptic Studies 17 (2015): 85-107.

Kemp, Sandra, Charlotte Mitchell, and David Trotter. The Oxford Companion to Edwardian Fiction. Oxford: Oxford University Press 1997. 
King, Karen. What is Gnosticism? Cambridge: Harvard University Press 2003.

Krause, Martin. 'Coptological Studies,' in Claremont Coptic Encyclopedia, ed. Aziz Suryal Atiya. New York: Macmillan 1991, 613a-616b.

Layton, Bentley. The Gnostic Scriptures: A New Translation with Annotations and Introductions. Garden City, NY: Doubleday 1987.

Layton, Bentley. 'Prolegomena to the Study of Ancient Gnosticism,' in L. White and L.M. Yarbrough (eds.), The Social World of the First Christians. Minneapolis: Fortress Press 1995, 334-350.

Linjamaa, Paul. 'Review of Stanley E. Porter and David Yoon, Paul and Gnosis (Leiden: Brill 2016),' in Svensk exegetisk årsbok 87 (2017): 291-294.

Linjamaa, Paul. The Ethics of The Tripartite Tractate (NHC I, 5): A Study of Determinism and Early Christian Philosophy of Ethics. Leiden: Brill 2019.

Linjamaa, Paul. 'Mocked by the Archon of Lust": Panarion 1.26 and Epiphanius' Hyperboles on Sex and Ascetics Read in light of Fourth-Century Ecclesiastical Debates,' Vigiliae Christianae 74:3 (2020): 316-334.

van Luijk, Ruben. Children of Lucifer:The Origins of Modern Religious Satanism. Oxford: Oxford University Press 2016.

McIntosh, Christopher. Éliphas Lévi and the French Occult Revival. London: Rider 1975 [1972].

Nilsson, Johan. China and the mystic 'East' in Occultism. Dissertation, Lund University 2020.

Oort, Johannes van. 'Another Case of Human Semen Eucharist Among the Manichaeans?,' Vigiliae Christianae 70 (2016): 430-440.

Pagels, Elaine. The Gnostic Gospels. New York: Vintage Books 1979.

Pardee, Cambry. 'The Gnostic Magdalene: Mary as Disciple and Revealer,' in Mary Magdalene from the New Testament to the New Age and Beyond, ed. Edmondo F. Lupieri. Leiden: Brill 2O2O, 50-78.

Pasi, Marco. 'Ordo Templi Orientis,' Dictionary of Gnosis and Western Esotericism, ed. W. Hanegraaff. Leiden: Brill 2006, 898-9o6.

Pearson, Joanne. Wicca and the Christian Heritage: Ritual, Sex and Magic. London: Routledge 2007.

Rasimus, Tuomas. Paradise Reconsidered in Gnostic Myth-making: Rethinking Sethianism in Light of the Ophite Evidence. Leiden: Brill 2009.

Robertson, David G. 'A Gnostic History of Religions,' Method and Theory in the Study of Religion 32 (2020): 75-88.

Robertson, David G. Gnosticism and the History of Religions. London: Bloomsbury Academic 2021.

Sedgwick, Mark. Against the Modern World: Traditionalism and the Secret Intellectual History. Oxford: Oxford University Press 2004.

Smith, Jonathan Z. Drudgery Divine: On the Comparison of Early Christianities and the Religions of Late Antiquity. Chicago: University of Chicago Press 1990. 
Smith, Morton. 'The History of the term Gnostikos,' in The Rediscovery of Gnosticism: Proceedings of the International Conference on Gnosticism at Yale, New Haven, Connecticut, March 28-31, 1978. Volume 2: Sethian Gnosticism, ed. Bentley Layton. Leiden: Brill 1981, 796-807.

Spjut, Petter. 'Pistis Sophia and the Chimera of Gnostic Origins,' Chapter in forthcoming dissertation, Uppsala.

Strube, Julian. 'Occultist Identity Formations Between Theosophy and Socialism in finde-siècle France,' Numen 64 (2017): 568-595.

Strube, Julian. Sozialismus, Katholizismus und Okkultismus im Frankreich des 19. Jahrhunderts: Die Genealogie der Schriften von Eliphas Lévi. Berlin: De Gruyter, 2016.

Toth, Ladislaus. 'Gnostic Church,' in Dictionary of Gnosis and Western Esotericism, ed. W. Hanegraaff. Leiden: Brill 2006, 400-403.

Urban, Hugh. 'The Knowing of Knowing: Neo-Gnosticism, from the o.T.o. to Scientology,' Gnosis 4 (2019): 99-116.

Williams, Michael. Rethinking “Gnosticism”: An Argument for Dismantling a Dubious Category. Princeton: Princeton University Press 1996.

Winter, Franz. 'Studying the "Gnostic Bible": Samael Aun Weor and the Pistis Sophia,' International Journal for the Study of New Religions 9.1 (2018): 83-112. 